\title{
SIKAP MAHASISWA TERHADAP PESAN PENGINGAT DONOR DARAH DENGAN TEKNOLOGI SMS GATEWAY
}

\author{
Ayulia Fardila Sari, Adi Heru Husodo, Lutfan Lazuardi \\ Universitas Gadjah Mada, Program Pascasarjana Fakultas Kedokteran, \\ Daerah Istimewa Yogyakarta \\ jmkbengkulu@gmail.com
}

\begin{abstract}
According to the World Health Organization (WHO) blood supply recommendation, Indonesia has 2.5 million blood bags less than it is needed. The majority of Indonesian people have already had mobile phones and thus favorable for the application of short message service (SMS). It is feaseable to use SMS in order to improve donor motivation. This study would like to evaluate students' attitude toward blood donor's message reminder using SMS from the Blood Donors Directory, Faculty of Medicine, Gadjah Mada University. It was a quantitative study with cross-sectional design. Undergraduate medical students recorded in the database of Blood Donors Directory Faculty of Medicine, Gadjah Mada University were chosen as the study population. Simple random sampling was applied to choose the subjects. This study used the framework of Technology Acceptance Model (TAM) and data were analyzed using Partial Least Square based Structural Equation Modelling (SEM). Attitude of blood donor's message reminder significantly influenced perceived ease of use and perceived usefulness of SMS technology. Attitude of blood donor's message reminder significantly influenced perceived entertainment, irritation, as well as credibility of message content. No significantly influenced by perceived informative. The intention to donate blood were significantly influenced by the attitude of blood donor's message reminder. Students' attitude in donating blood was positively influenced by good perception about ease of use and usefulness of SMS technology. It was also positively influenced by positive perception to entertaining and credible messages, as well as negative perception to irritating messages. The positive attitude towards donor's message reminder would support the intention to behave as blood donors.
\end{abstract}

Keywords : SMS gateway, attitudes toward SMS, blood donation, TAM, SEM, PLS

\begin{abstract}
Abstrak: Indonesia masih kekurangan sekitar 2,5 juta kantung darah per tahun berdasarkan rekomendasi kebutuhan darah oleh WHO. Penerapan sistem SMS gateway dalam rangka meningkatkan motivasi pendonor sangat mungkin dilakukan karena sebagian besar masyarakat Indonesia sudah memiliki telepon seluler. Penelitian ini mengevaluasi sikap mahasiswa terhadap pesan pengingat donor darah dengan teknologi SMS gateway di Direktori Donor Darah Fakultas Kedokteran Universitas Gadjah Mada (FK UGM). Penelitian ini merupakan jenis penelitian kuantitatif dengan rancangan cross sectional. Subjek penelitian adalah mahasiswa Strata 1 (S-1) FK UGM yang tercatat pada basis data Direktori Donor Darah FK UGM dan dipilih dengan metode acak sederhana. Penelitian ini menggunakan kerangka Technology Acceptance Model (TAM) dan dianalisis menggunakan metode Structural Equation Modelling (SEM) berbasis Partial Least Square (PLS). Dari hasil penelitian ini terungkap bahwa sikap terhadap SMS pengingat donor darah dipengaruhi secara signifikan oleh persepsi kemudahan penggunaan.persepsi kegunaan teknologi SMS. Dan juga dipengaruhi secara signifikan oleh persepsi terhadap isi pesan yang menghibur, SMS yang mengganggu, dan kredibilitas. Tidak ada pengaruh signifikan terhadap persepsi isi pesan yang informatif. Sikap terhadap SMS pengingat donor darah berpengaruh signifikan pada minat perilaku melakukan donor darah. Sikap positif mahasiswa terhadap pesan pengingat donor akan mendorong munculnya minat untuk berperilaku sebagai pendonor darah.
\end{abstract}

Kata kunci: SMS gateway, sikap terhadap SMS, donor darah, TAM, SEM, PLS 
Ketersediaan darah berperan penting dalam menunjang pelayanan kesehatan terutama dalam penanganan pasien dengan kegawatdaruratan medis yang memerlukan transfusi darah maupun pasien dengan gangguan produksi darah ataupun komponen darah. Misalnya pasien dengan anemia berat, penyakit gangguan darah bawaan, pasien yang akan menjalankan tindakan bedah, kasus perdarahan maupun penyakit lainnya (Weiser TG, et al, 2008). WHO (20090) menetapkan jumlah persediaan darah yang ideal di suatu negara adalah minimal $1-2 \%$ dari jumlah penduduk. Sesuai dengan rekomendasi tersebut maka saat ini kebutuhan darah di Indonesia adalah $\pm 4,5$ juta kantung/tahun. Namun demikian, data dari Unit Transfusi Darah (UTD) Palang Merah Indonesia (PMI) menyebutkan bahwa Indonesia baru dapat mencukupi 2 juta kantung darah/tahun.

Indonesia adalah negara yang memiliki jumlah pendudukterbanyak di Asia Tenggara. Tingginya jumlah penduduk di Indonesia tidak diiringi dengan tingkat donasi darah yang hanya 6 orang per 1000 penduduk. Jumlah ini sangat rendah jika dibandingkan tingkat donasi di negara Asia Tenggara lainnya seperti Malaysia 10 per 1000 penduduk, Thailand 13 per 1000 penduduk, dan Singapura 24 per 1000 penduduk (WHO, 2009). Berbagai upaya dibutuhkan dalam rangka meningkatkan jumlah pendonor sukarela dan mencukupi kebutuhan darah, salah satunya melalui pemanfaatan fasilitas SMS pada telepon seluler.

Aplikasi SMS sudah banyak diterapkan pada sektor kesehatan. SMS untuk pengingat digunakan dalam mengatur perilaku kesehatan pasien diabetes tipe 2 dan pengingat berbasis SMS untuk mencegah drop out pengobatan tuberculosis (Vervloet M, et al, 2012). Penelitian-penelitian tersebut terbatas dalam mengukur manfaat langsung terhadap pesan SMS, sehingga sangat mungkin dilakukan penelitian yang mengukur manfaat tidak langsung bagi penerima seperti aktivitas sosial melakukan donor darah.

Penggunaan aplikasi SMS untuk promosi donor darah sudah pernah dilakukan sebelumnya. Penelitian di Malawimengukur hubungan antara sikap responden terhadap teknologi SMS dan keinginan untuk melakukan donor darah setelah menerima pesan pengingat. Penelitian di India melakukan tele-recruitment dengan telepon dan SMS untuk meningkatkan jumlah pendonor sukarela yang mau melakukan donor darah secara rutin (Gombachika H, 2011). Kedua penelitian ini terbatas hanya menggunakan pendonor darah sebagai subjek penelitian. Telerecruitment membantu pusat pelayanan darah dalam menjaga hubungan personal dengan pendonor dan masyarakat pada umumnya. Pengiriman pesan motivasi sederhana akan memunculkan ketertarikan dan minat penerima dalam melakukan donor darah (Agrawal A, et al, 2012). Penelitian yang mengukur penerimaan pendonor dan non-donor perlu dilakukan mengingat rendahnya tingkat donasi dan rendahnya jumlah pendonor sukarela di Indonesia.

TAM merupakan suatu model penerimaan sistem teknologi informasi yang akan digunakan oleh pemakai. TAM dikembangkan oleh Davis (1989) berdasarkan Theory of Reason Action (TRA). Menurut TAM, Persepsi kegunaan (PU) dan persepsi kemudahan penggunaan (PEOU) suatu teknologi mempengaruhi sikap terhadap perilaku (Actual Technology Use/ATU). Sikap ini akan mempengaruhi minat untuk berperilaku (Behavioral Intention to Use/BITU) yang akan menentukan seseorang untuk berperilaku (behavior) (Davis FD, et al, 1989). Sikap penerima terhadap konten SMS memiliki peran penting terhadap penerimaan dan kepatuhan melakukan apa yang disarankan oleh isi SMS tersebut. SMS promosi (iklan) yang memiliki unsur hiburan (entertainment), informatif (informative), tidak mengganggu (irritation), dan kredible (credibility) memiliki pengaruh positif terhadap sikap penerima (Tsang MM, et al, 2009).

Kementerian Informatika dan Komunikasi Republik Indonesia menyatakan bahwa jumlah pengguna telepon selular di Indonesia hingga tahun 2011 mencapai 231 juta. Kondisi ini menyebabkan penggunaan teknologi telepon seluler sangat mungkin untuk meningkatkan motivasi pendonor khususnya anak muda. Penelitian Unal et al. (2011) menyatakan bahwa promosi dan pemasaran melalui teknologi 
telepon seluler lebih diterima dengan baik oleh anak muda daripada orang dewasa. Penelitian ini akanmengukur sikap mahasiswa terhadap SMS pengingat donor darah dari penerimaan isi pesan. Hasil penelitian diharapkan menambah kajian dan pengembangan tentang media promosi donor darah untuk masa yang akan datang. Berdasarkan latar belakang tersebut, hipotesis penelitian ini adalah sebagai berikut: persepsi kemudahan penggunaan SMS pengingat (PEOU) mempengaruhi sikap terhadap penerimaan SMS pengingat donor darah (ATU), persepsi kegunaan SMS pengingat (PU) mempengaruhi sikap terhadap penerimaan SMS pengingat donor darah (ATU), persepsi SMS pengingat sebagai hiburan (PE) mempengaruhi sikap terhadap penerimaan SMS pengingat donor darah (ATU), persepsi SMS pengingat bersifat informatif (PI) mempengaruhi sikap terhadap penerimaan SMS pengingat donor darah (ATU), persepsi SMS pengingat sebagai gangguan (PIR) mempengaruhi sikap terhadap penerimaan SMS pengingat donor darah (ATU), persepsi kredibilitas SMS pengingat (PC) mempengaruhi sikap terhadap penerimaan SMS pengingat donor darah (ATU) dan sikap penerimaan SMS pengingat donor darah (ATU) mempengaruhi minat melakukan donor darah (BITU).

Penelitian ini bertujuan untuk mengevaluasi sikap mahasiswa terhadap pesan pengingat donor darah dengan teknologi SMS gateway di Direktori Donor Darah Fakultas Kedokteran Universitas Gadjah Mada (FK UGM).

\section{BAHAN DAN CARA KERJA}

Penelitian ini merupakan jenis penelitian kuantitatif dengan rancangan cross sectional. Penelitian dilakukan di Fakultas Kedokteran Universitas Gadjah Mada.Populasi penelitian ini adalah peserta yang tercatat pada basis data Direktori Donor Darah FK UGM. Data yang sudah tercatat lengkap beserta nomor telepon selulernya adalah mahasiswa S1 FK UGM angkatan 2012 dan 2013 yang terdiri dari tiga program studi. Kriteria inklusi sampel dari populasi adalah bersedia menerima SMS pengingat dan memiliki telepon seluler (handphone) dengan kartu SIM yang aktif selama penelitian berlangsung. Kriteria eksklusi sampel dari populasi adalah tidak bersedia mengisi kuesioner evaluasi.

Populasi penelitian ini memiliki karak-teristik relatif homogen sehingga digunakan teknik pengambilan probabilistik dengan acak sederhana (simple random sampling). Pada penelitian ini jumlah populasi adalah 678 orang dan kesalahan yang ditolerir sebesar $10 \%$, sehingga jumlah sampel minimal adalah 88 .

Penelitian dilakukan selama lebih kurang 4 bulan. Bulan pertama adalah perancangan isi SMS pengingat. Pesan yang akan dikirimterdiri dari 1 ucapan selamat ulang tahun, 10 pesan motivasi mengenai donor darah, dan 1 pesan informasi even donor darah. Bulan kedua dan ketiga adalah pengiriman pesan motivasi yang dilakukan dengan frekuensi 2-3 pesan per minggu. Bulan keempat adalah pengisian kuesioner oleh responden. Kuesioner berisi pertanyaan mengenairesponterhadap SMS pengingat, penerimaan responden terhadap isi pesan SMS, dan preferensi saluran komunikasi. Penelitian ini menggunakan item-item kuesioner dari penelitian sebelumnya yang telah teruji validitas dan reliabilitasnya.

Kuesioner evaluasi penerimaan terhadap teknologi SMS dan isi pesan sistem pengingat donor darah berbasis pesan teks disebarkan kepada responden menggunakan kuesioner online. Kuesioner online dibuat menggunakan aplikasi google docs dan bisa diakses melalui internet pada telepon seluler maupun komputer. Alamat URL atau link untuk mengakses kuesioner disampaikan kepada responden melalui SMS dan surat elektronik (email).

Analisis deskriptif kuesioner penelitian menggunakan aplikasi statistik SPSS. Analisis untuk uji validitas, uji reliabilitas, dan pengujian hipotesis menggunakan kerangka pemodelan persamaan struktur (SEM) berbasis varians, yaitu PLS. Structural Equation Modelling adalah suatu teknik statistika untuk menguji dan mengestimasi hubungan kausal dengan mengintegrasikan analisis faktor dan analisis jalur. PLS adalah salah satu metode statistik SEM berbasis varian yang didesain untuk menyelesaikan regresi berganda ketika terjadi permasalahan spesifik pada data, seperti ukuran 
sampel penelitian relatif kecil, adanya data yang hilang, dan multikolinearitas (Jogiyanto, 2009). Pada penelitian ini, alat statistik yang digunakan sebagai alat bantu SEM adalah SmartPLS.

\section{HASIL}

\section{Karakteristik Subjek Penelitian}

Subjek penelitian adalah responden yang mengisi kuesioner dengan lengkap.Subjek pada penelitian ini berjumlah 133 orang dengan mayoritas berjenis kelamin perempuan $(84,2 \%)$. Responden terbanyak berasal dari Program Studi Pendidikan Dokter $(45,8 \%)$ dan rerata usia responden adalah 19 tahun. Diketahui bahwa 86,4\% subjek penelitian belum pernah mendonasikan darahnya. Karakteristik subjek penelitian selengkapnya ditampilkan oleh Tabel 1 dan 2.

Tabel 1 Karakteristik Subjek Penelitian

\begin{tabular}{ccc}
\hline Variabel & $\begin{array}{c}\text { Frekuensi } \\
(\mathbf{n = 1 3 3 )}\end{array}$ & $\begin{array}{c}\text { Presentase } \\
(\mathbf{1 0 0 \%})\end{array}$ \\
\hline Usia (tahun) & 8 & \\
21 & 28 & 5,9 \\
20 & 56 & 43,0 \\
19 & 10 & 71,5 \\
18 & 1 & 0,4 \\
17 & & \\
Jenis Kelamin & 21 & 15,8 \\
Laki-Laki & 112 & 84,2 \\
Perempuan & & \\
Angkatan & 75 & 56,4 \\
2013 & 58 & 43,6 \\
2012 & & \\
Program Studi & 61 & 45,8 \\
Pendidikan Dokter & 31 & 23,3 \\
Ilmu Keperawatan & 41 & 30,8 \\
Gizi Kesehatan & & \\
Donor Darah & 18 & 13,5 \\
Pernah & 115 & 86,4 \\
Belum Pernah & & \\
\hline
\end{tabular}

Tabel 2 Karakteristik Subjek Penelitian berdasarkan akseptansi

\begin{tabular}{lcc}
\hline Akseptansi & $\begin{array}{c}\text { Frekuensi } \\
(\mathbf{n = 1 3 3 )}\end{array}$ & $\begin{array}{c}\text { Presentase } \\
(\mathbf{1 0 0 \%})\end{array}$ \\
\hline Saya Bersedia Menerima: & & \\
$\quad$ 1 SMS Pengingat & 58 & 43,6 \\
2 SMS Pengingat & 24 & 18,0 \\
4 SMS Pengingat & 7 & 5,3 \\
$\quad$ > 4 SMS Pengingat & 40 & 30,1 \\
$\quad$ Tidak ada SMS pengingat & 4 & 3,0 \\
Apa yg anda lakukan ketika & & \\
menerima SMS pengingat: & & \\
$\quad$ Tidak bersedia & 21 & 15,8 \\
$\quad$ Langsung donor darah & 1 & 0,8 \\
$\quad$ Menyusun rencana utk & 111 & 83,5 \\
$\quad$ mendonasikan darah & & \\
\hline
\end{tabular}

\section{Pengujian Validitas dan Reliabilitas}

Validitas dan reliabilitas penelitian diukur dengan nilai konvergen validitas (convergent validity), composite reliability, Average Variance Extracted (AVE), dan Alpha Cronbach's. Nilai konvergen validitas didasarkan pada nilai korelasi antara indikator dengan konstrak latennya yang disebut dengan loading indicator.Konvergen validitas dikatakan tinggi jika korelasi lebih dari 0,7. Seluruh konstruk laten pada penelitian ini memiliki nilai loading indicator yang memenuhi persayaratan valid.

Berdasarkan pengolahan data, seluruh konstruk memiliki nilai composite reliability> 0,7 . Kriteria nilai composite reliability $>0,7$ menunjukkan bahwa indikator tersebut memiliki internal konsistensi yang baik. Nilai composite reliability yang tinggi menunjukkan adanya konsistensi yang baik dari setiap indikator dalam konstrak laten untuk mengukur konstrak tersebut.Begitu juga dengan nilai AVE pada tiap konstruk penelitian sesuai dengan yang diharapkan, yaitu >0,5. Semakin besar varian atau keragaman indikator yang dikandung konstrak laten, maka semakin besar representasi indikator terhadap konstrak latennya. Uji reliabilitas diperkuat dengan nilai alpha cronbach's. Pada penelitian ini didapat bahwa semua nilai sesuai dengan batasan uji reliabilitas alpha cronbach $>0,7$.

\section{Pengujian Hipotesis}

Pengujian selanjutnya adalah melihat signifikansi pengaruh antar konstrak laten dan menjawab apa yang telah dihipotesiskan. Nilai koefisien parameter (original sample) dan nilai signifikansi t-statistik dapat dilihat. Hasil pengujian hipotesis sebagai berikut :

\section{Hipotesis 1}

Besarnya nilai koefisien pengaruh persepsi kemudahan penggunaan SMS pengingat (PEOU) terhadap sikap penerimaan SMS pengingat donor darah (ATU) sebesar 0,1631 dan nilai t-statistik sebesar 2,2571. Nilai tstatistik 2,2571 lebih besar dari t-tabel 1,64 maka keputusan menolak H0, artinya persepsi kemudahan penggunaan SMS pengingat (PEOU) berpengaruh signifikan terhadap sikap 
penerimaan SMS pengingat donor darah (ATU).

\section{Hipotesis 2}

Besarnya nilai koefisien pengaruh persepsi kegunaan SMS pengingat (PU) terhadap sikap penerimaan SMS pengingat donor darah (ATU) sebesar 0,1405 dan nilai t-statistik sebesar 2,2499. Nilai t-statistik 2,2499 lebih besar dari t-tabel 1,64 maka keputusan menolak $\mathrm{H} 0$, artinya persepsi kegunaan SMS pengingat (PU) berpengaruh signifikan terhadap sikap penerimaan SMS pengingat donor darah (ATU).

\section{Hipotesis 3}

Besarnya nilai koefisien pengaruh persepsi SMS Pengingat sebagai hiburan (Entertainment $=\mathrm{PE}$ ) terhadap sikap penerimaan SMS pengingat donor darah (ATU) sebesar 0,575 dan nilai t-statistik sebesar 7,9753. Nilai t-statistik 7,9753 lebih besar dari t-tabel 1,64 maka keputusan menolak H0, artinya persepsi SMS pengingat sebagai hiburan (Perceived Entertainment/PE) berpengaruh signifikan terhadap sikap penerimaan SMS pengingat donor darah (ATU).

\section{Hipotesis 4}

Besarnya nilai koefisien pengaruh persepsi SMS Pengingat yang Informatif (Perceived Infotainment/PI) terhadap sikap penerimaan SMS pengingat donor darah (ATU) sebesar 0,0116 dan nilai t-statistik sebesar 0,1762 . Nilai t-statistik 0,1762 lebih kecil dari t-tabel 1,64 maka keputusan menerima H0, artinya persepsi SMS Pengingat bersifat informatif (PI) tidak berpengaruh terhadap sikap penerimaan SMS pengingat donor darah (ATU).

\section{Hipotesis 5}

Besarnya nilai koefisien pengaruh persepsi SMS pengingat sebagai gangguan atau menjengkelkan (Perceived Irritation/PIR) terhadap sikap penerimaan SMS pengingat donor darah (ATU) sebesar -0,0959 dan nilai tstatistik sebesar 1,8423. Nilai t-statistik 1,8423 lebih besar dari t-tabel 1,64 maka keputusan menolak H0, artinya persepsi SMS pengingat sebagai gangguan (PIR) berpengaruh signifikan terhadap sikap penerimaan SMS pengingat donor darah (ATU).

\section{Hipotesis 6}

Besarnya nilai koefisien pengaruh persepsi kredibilitas SMS pengingat (PC) terhadap sikap penerimaan SMS pengingat donor darah (ATU) sebesar 0,1427 dan nilai t-statistik sebesar 1,8025. Nilai t-statistik 1,8025 lebih besar dari t-tabel 1,64 maka keputusan menolak H0, artinya bahwa persepsi kredibilitas SMS pengingat (PC) berpengaruh signifikan terhadap sikap penerimaan SMS pengingat donor darah (ATU).

\section{Hipotesis 7}

Besarnya nilai koefisien pengaruh sikap penerimaan SMS pengingat donor darah (ATU) terhadap minat perilaku melakukan donor darah (BITU) sebesar 0,2384 dan nilai t-statistik sebesar 2,0151. Nilai t-statistik 2,0151 lebih besar dari t-tabel 1,64 maka keputusan menolak H0, artinya bahwa sikap penerimaan SMS pengingat donor darah (ATU) berpengaruh signifikan terhadap minat perilaku melakukan donor darah (BITU).

\section{PEMBAHASAN}

Persepsi positif terhadap SMS pengingat sebagai hiburan (PE) berpengaruh positif terhadap sikap penerimaan SMS pengingat donor darah (ATU). Persepsi hiburan pada konteks ini berkaitan dengan akseptansi dan kenyamanan mahasiswa terhadap isi pesan. Persepsi yang positif berkaitan dengan isi pesan yang mudah dipahami dan ringkas yaitu maksimal 150 karakter. Hiburan merupakan salah satu faktor penting dalam SMS promosi dimana pesan tersebut harus pendek, ringkas, dan menarik. Anak muda lebih menyukai pesan SMS yang pendek sehingga lebih mudah diingat (Unal et al, 2011).

Persepsi negatif terhadap SMS pengingat yang mengganggu (PIR) berpengaruh positif terhadap sikap penerimaan SMS pengingat donor darah (ATU). Persepsi gangguan berkaitan dengan respon negatif penerima yang merasa terganggu dan jengkel karena SMS pengingat. Berdasarkan pengolahan data, hanya $3 \%$ 
responden yang tidak bersedia menerima SMS pengingat donor darah dan hanya 15,8\% responden yang menolak untuk mendonasikan darah ketika menerima SMS Pengingat. Pesan yang dikirim pada penelitian ini meminta persetujuan dari penerima sehingga penerima tidak merasa terganggu. Penelitian Tsang et al. (2004) dan Unal et al. (2011) menyatakan bahwa terdapat sikap negatif dari konsumen yang menerima SMS promosi, namun berubah positif setelah mereka memberi izin untuk menerima SMS promosi (Tsang MM, et al, 2004).

Persepsi kredibilitas SMS pengingat (PC) berpengaruh positif terhadap sikap penerimaan SMS pengingat donor darah (ATU). Persepsi kredibilitas berkaitan dengan tingkat kepercayaan individu terhadap SMS pengingat. SMS yang dikirim pada penelitian ini disertai identitas pengirim yang bertujuan untuk menjamin kredibilitas pesan.Setiap pelaksanaan broadcast, peneliti hanya menggunakan satu nomor kartu sim dan menyertai frasa "\#DirDonDarFKUGM" di akhir isi pesan sebagai akronim dari pengirim, yaitu Direktori Donor Darah FK UGM. SMS yang disertai dengan identitas pengirim membuat pesan lebih personal dan kredibel (Cantu, et al, 2012).

Persepsi SMS pengingat bersifat informatif (PI) tidak berpengaruh signifikan terhadap sikap penerimaan SMS pengingat donor darah (ATU). Hasil ini berbeda dengan hipotesis penelitian yaitu persepsi SMS pengingat yang informatif mempengaruhi sikap penerimaan SMS pengingat donor darah. Tidak adanya pengaruh disebabkan oleh isi SMS yang dikirim belum menyediakan informasi yang dibutuhkan oleh mahasiswa.Subjek penelitian yang merupakan mahasiswa fakultas kedokteran relatif sudah memiliki pemahaman yang baik mengenai informasi kesehatan dan donor darah. Altuna \& Konuk (2009) menyatakan bahwa dimensi informatif berkaitan dengan kemampuan pesan promosi (iklan) menyediakan informasi terkini, tepat waktu, dan dibutuhkan oleh penerima.

Persepsi informatif tidak menentukan penerimaan seseorang terhadap isi pesan SMS juga disebabkan oleh perbedaan kebutuhan individu terhadap informasi sehingga lebih memilih mencari informasi dari layanan lain seperti internet dan buku dibandingkan melalui layanan SMS. Menurut Sadeh (2002) fungsi utama SMS sebagai saluran komunikasi dengan jumlah isi pesan yang tidak lebih dari 160 karakter sehingga pengguna cenderung memperoleh informasi dari layanan lain yang menawarkan informasi lebih lengkap. Godin et al. (2012) menyatakan bahwa pesan yang memiliki unsur motivasi dan pengingat adalah intervensi paling efektif dalam meningkatkan jumlah pendonor.

Perbedaan hasil penelitian dengan hipotesis penelitian juga disebabkan oleh karakteristik responden yang sebagian besar adalah perempuan $(84,2 \%)$ dan berusia muda, yakni rerata berusia 19 tahun. Hasil penelitian Gombachika \& Monawe (2011) menyatakan bahwa karakteristik individu menentukan sikap mereka terhadap SMS pengingat donor darah. Pria dan orang yang berusia dewasa lebih menyukai isi pesan yang bersifat informatif dibandingkan dengan wanita dan anak muda yang cenderung menyukai isi SMS yang memiliki unsur hiburan.

Subjek penelitian ini adalah mahasiswa fakultas kedokteran yang $86,4 \%$ belum pernah melakukan donasi. Pada penelitian ini tampak bahwa pengaruh positif terhadap sikap penerima SMS tidak hanya dari pendonor namun juga dari orang yang belum pernah donasi (non-donor). Mayoritas mahasiswa merasa nyaman, tidak terganggu, dan percaya dengan SMS donor darah yang diterima. Hal tersebut tampak dari hasil analisis kuesioner penelitian dimana 90,2\% responden memilih SMS sebagai saluran komunikasi yang paling sering digunakan dan 97\% responden bersedia menerima SMS pengingat donor darah dengan jumlah SMS yang bervariasi mulai dari 1 SMS hingga lebih dari 4 SMS. Sikap positif mahasiswa juga terlihat dari mayoritas responden $(83,5 \%)$ yang akan menyusun rencana untuk mendonasikan darah setelah menerima SMS pengingat.

Sikap positif terhadap penerimaan pesan pengingat donor darah melalui media teknologi SMS diharapkan dapat memunculkan minat dan 
perilaku berdonor di masa yang akan datang. Sikap terhadap pesan promosi memiliki pengaruh signifikan terhadap minat perilaku seseorang (Tsang MM, et al, 2004). Minat untuk menggunakan teknologi (BITU) adalah kecenderungan perilaku untuk tetap menggunakan suatu teknologi. Tingkat penggunaan sebuah teknologi komputer pada seseorang dapatdiprediksi dari sikap perhatiannya terhadap teknologi tersebut, misalnya keinginan menambah peripheral pendukung, motivasi untuk tetap menggunakan, serta keinginanuntuk memotivasi pengguna lain (Davis FD, 1989). Menurut Masser et al. (2008) sikap adalah salah satu faktor yang dapat memprediksi niat nondonor dalam melakukan donor darah. Pada penelitian ini, minat terhadap SMS pengingat donor darah dapat diketahui dari sikap yang positif dengan tidak keberatan untuk menerima SMS pengingat donor darah, memberi perhatian terhadap isi pesan, muncul niat untuk mendonasikan darah, dan mengajak orang-orang disekitarnya untuk melakukan donor darah.

\section{KESIMPULAN}

Sikap penerimaan mahasiswa terhadap teknologi SMS secara signifikan dipengaruhi oleh persepsi kemudahan penggunaan (PEOU)

\section{DAFTAR RUJUKAN}

Agrawal A, Tiwari A. Tele-recruitment for Donor Retention. Indian Journal of Hematology and Blood Transfusion. Springer-Verlag; 2012;1-4.

Altuna OK, Konuk FA. Understanding Consumer Attitudes Toward Mobile Advertising and Its Impact on Consumer's Behavioral Intention: a Cross - Market Comparison OF United Stated and Turkish Consumers. International Journal of Mobile Marketing. 2009;4(2):43-52.

Barwise, P., \& Strong, C. Permission-Based Mobile Advertising. Journal of Interactive Marketing. 2002. 16(I).

Cantu M, H MP, Sheoran B, A MH, Chung PJ, S M. Adolescents 'Perspectives on the Use of a Text Messaging Service for Preventive Sexual Health Promotion. Journal of Adolescent Health [Internet]. Elsevier 2012;51(3):220-5.

Godin G, Bélanger-gravel A, Amireault S. Efficacy of Interventions Promoting Blood Donation. Transfusion Medicine Reviews [Internet]. Elsevier Inc.; 2012;26(3):224-237.e6. dan persepsi kegunaan (PU) teknologi SMS. Sikap penerimaan terhadap isi pesan SMS pengingat donor darah secara signifikan dipengaruhioleh persepsi positif SMS yang memiliki unsur hiburan (PE), persepsi negatif mengenai SMS yang mengganggu (PIR), dan persepsi positif terhadap kredibilitas SMS (PC). Sikap terhadap SMS pengingat donor darah (ATU) berpengaruh signifikan terhadap minat melakukan donor darah (BITU). Sikap penerimaan mahasiswa terhadap pesan pengingat donor akan mendorong munculnya minat untuk berperilaku sebagai pendonor darah.

Disarankan pada Direktori Donor Darah FK UGM untuk melanjutkan mengirim SMS pengingat donor darah yang tidak lebih dari 160 karakter, mencantumkan identitas pengirim, serta memiliki unsur hiburan dan menggugah jiwa sosial penerima. Perlu dilakukan penelitian lanjutan dengan mempertimbangkan subjek penelitian yang diganti dengan pendonor darah saja.Selain itu penelitian lanjutan yang tidak hanya mengukur respon terhadap media SMS, tapi menggunakan media komunikasi lainnya seperti media sosial populer: twitter, facebook, BBM, whatsapp, line, dll juga dapat dipertimbangkan.

Gold, J., Lim, M. S. C., Hellard, M. E., Hocking, J. S., \& Keogh, L. What's in a message? Delivering sexual health promotion to young people in Australia via text messaging. BMC public health. 2010. 10(1), 792. doi:10.1186/1471-2458-10-792

Gombachika H, Monawe M. Correlation Analysis of Attitudes towards SMS Technology and Blood Donation Behaviour in Malawi. Journal of Health Informatics in Developing Countries. 2011;25972.

Jogiyanto, Abdillah W. Konsep dan Aplikasi PLS untuk Penelitian Empiris. Yogyakarta: BPFE; 2009.

Mandy WMT. Consumer's Attitude Towards Mobile Advertising. The Hong Kong Polytechnic University; 2009.

Masser, B. M., White, K. M., Hyde, M. K., \& Terry, D. J. The Psychology of Blood Donation: Current Research and Future Directions. Transfusion Medicine Reviews. 2008. 22(3), 215-233. doi:10.1016/j.tmrv.2008.02.005

Ridha A, Paramastri I, Wibowo TA. Motivasi melalui layanan pesan singkat telepon seluler pada perilaku merokok: Studi di Universitas Muhammadiyah Pontianak. Universitas Gadjah Mada; 2012. 
Sadeh N. M-Commerce, Technologies, Services, and Business Models [Internet]. Long CA, editor. Canada: John Wiley \& Sons; 2002.

Schantz-Dunn J, Nour NM. The Use of Blood in Obstetrics and Gynecology in the Developing World. Women's Health in the Developing World. 2011;4(2):86-91.

Soroa-koury S, Yang KCC. Factors affecting consumers' responses to mobile advertising from a social norm theoretical perspective. Telematics and Informatics [Internet]. Elsevier Ltd; 2008;27(1):103-13.

Tsang MM, Ho S, Liang T. Consumer Attitudes toward Mobile Advertising: An Empirical Study. International Journal of Electronic Commerce. 2004;8(3):65-78.

Umar H. Metode Penelitian untuk Skripsi dan Tesis Bisnis. Depok: Rajagrafindo Persada; 2013. p. 78.

Unal S, Ercis A, Keser E. Attitudes towards Mobile Advertising - A Research to Determine the Differences between the Attitudes of Youth and Adults. Procedia - Social and Behavioral Sciences [Internet]. 2011 Jan [cited 2013 Sep 17];24:36177.

Vervloet M, Dijk LV, Vlijmen BV, Wingerden PV, Bouvy ML, Bakker DHD. SMS reminders improve adherence to oral medication in type 2 diabetes patients who are real time electronically. International Journal of Medical Informatics [Internet]. Elsevier Ireland Ltd; 2012;81(9):594 604.

Weiser TG, Regenbogen SE, Thompson KD, Haynes AB, Lipsitz SR, Berry WR, et al. An estimation of the global volume of surgery: a modelling strategy based on available data. Lancet [Internet]. $2008 \mathrm{Jul}$ 12 [cited 2014 Apr 29];372(9633):139-44.

World Health Organization. WHO Blood Safety Indicators 2007. Geneva, Switzerland; 2009.

$\mathrm{Xu}$ DJ. The Influence of Personalization in Affecting Consumer Attitudes Toward Mobile Advertising in China. Journal of Computer Information System. 2006;(9).

Zulfian, Nugroho E, Fuad A. Strategi Pengembangan Pengingat Berbasis SMS untuk Mencegah Drop Out Pengobatan Tuberkulosis di Balai Pengobatan Penyakit Paru-Paru (BP4) Banda Aceh Dinas Kesehatan Provinsi Nanggroe Aceh Darussalam. Universitas Gadjah Mada; 2009. p. 1-104. 